\title{
The Impact of Corporate Governance and Organizational Politics on Leadership Effectiveness/Ineffectiveness in the Nigerian Banking Sector
}

\author{
Chief Peter Odion Omoijiade ${ }^{1}$ \\ ${ }^{1}$ Abi Alchemy Business Intelligence, Nigeria \\ Correspondence: Chief Peter Odion Omoijiade, President/Executive Consultant, Abi Alchemy Business \\ Intelligence, 65, Kudirat Abiola Way, Oregun, Ikeja, Lagos, Nigeria. Tel: 234-80-2313-0658. E-mail: \\ pomoijiade@yahoo.co.uk or pomoijiade@gmail.com
}

Received: March 5, 2015

Accepted: March 24, 2015

Online Published: April 20, 2015

doi:10.5539/ijbm.v10n5p193

URL: http://dx.doi.org/10.5539/ijbm.v10n5p193

\begin{abstract}
This study aims at examining the impact of organizational politics and corporate governance on leadership effectiveness/ineffectiveness in the Nigerian banking sector. This study culminates in the building of organizational politics, corporate governance and leadership effectiveness/ineffectiveness and good corporate performance/poor corporate performance model. While good corporate governance elements will enhance good corporate performance, poor corporate governance elements will impair leadership effectiveness and hence poor corporate performance. In this study, I found that as a result of crime of obedience, those who occupy sensitive positions who are products of distributed advantages/disadvantages only serve the interest of their principals. Thus, the objective of monitoring, independence and control instituted for the enhancement of corporate governance are subverted.
\end{abstract}

Although the crime of obedience is within the rubrics of organizational politics, it is found in this study as a catalyst which triggers/acts on the elements in corporate governance. The enhancement of good corporate governance in the Nigerian banking sector cannot be dependent on self-equilibrating mechanism. To mitigate the harsh effect of organizational politics and enhance the elements of monitoring, independence and control in corporate governance, employees and their representatives must be allowed to exist to constrain the ability of the leadership to act arbitrarily. The attainment of this goal and a synergy between employees and their representatives and strong private sector empowerment regulation will enhance effective corporate governance in banks.

This study reflects the stance of interpretivism. Interpretevists are more liable in using action research. The adoption of action research is predicated on this premise. Although interpretivism is weak on ground of subjectivity, the strongest argument of the interpretivist is the necessity to discover the details of the situation and understand the reality working behind them.

This research will create the needed understanding of the extent to which organizational politics is a determinant of corporate governance configuration and hence leadership effectiveness/ ineffectiveness in the Nigerian banking sector.

Keywords: leadership, leadership effectiveness/ineffectiveness, corporate governance, organizational politics, power, crime of obedience

\section{Introduction}

Banking is an industry in the service sector (Jones, 1993). Hendrickson (2001), in his study undertaken in the United States of America banking industry demonstrates the correlation between a well-functioning banking system and a well-functioning economy. Banks have an impact on all sectors, through their lending policies, on large numbers of individuals through their deposit taking function; and on the general financial and monetary conditions of economies. Thus the banking activity remains a critical variable in the national development of countries. The way banks function in providing its traditional services has also changed drastically over the years due to the implementation of new technology in the sector. One of the most significant is electronic banking. 
These developments have made the management of these institutions more complex. There are various studies on leadership effectiveness/ineffectiveness. However, the impact of Corporate governance and organizational politics on leadership effectiveness/ ineffectiveness are yet to be explored. My research objectives therefore are as follows:

a) To determine if organizational politics is a determinant of corporate governance configuration in the Nigerian banking sector.

b) To determine if leadership effectiveness/ineffectiveness in the Nigerian banking sector is affected by organizational politics.

\subsection{Problem Analysis}

The Nigerian Banking Sector is on its road to perdition as unscientific management practices abound (Omoijiade, 2014a). Overtly aggressive growth policies, poor judgment as a result of poor bank management which were identified as some of the factors that contributed to the failure of banks in the past are still present (Ebhodaghe, 1994). The banks are yet to realize that their value chain is embedded in the customer's value chain (Omoijiade, 2014b). Mamman and Oluyemi (1994) found that in selecting or appointing people in failed banks, due attention was not given to qualification, managerial/professional experience, track records and integrity. The position of Mamman and Oluyemi is congruent with the study of Costa (2006), who noted that those in authority in a bank could bring misfortune to a bank through promotion of the wrong people, assignment of wrong position to people and hiring external talent without tapping the potentials which exist within the organization. The success of banks depends on the quality of its personnel as adequate capital may turn inadequate with bad management (Mamman \& Oluyemi, 1994; Kubr \& Wallace, 1983). The problem of leadership failure has worsened significantly in business, as vital resources are lost (Williams, 2006). The search for effective organizational leadership has been the goal of almost all companies in order to maximize their resources, not only in terms of financial capital, but also human and customer valuation capital. As noted by Collins (2009), "While no leader can single-handedly build an enduring great company, the wrong leader, vested with power can almost single handedly bring a company down". A critical review indicates that lack of good corporate governance and organizational politics are responsible for bad management and leadership ineffectiveness in the Nigerian banking sector. As an employee, you may have strength of character and dazzling in speed of thought and creativity, your career will degenerate to futile existence if you are inept in navigating through the political terrain of your organization. Thus, the effectiveness of organizational leadership and hence the corporate growth of a company is highly dependent on the existence of good corporate governance and the ability to control and moderate the harsh effects of organizational politics.

\subsection{Research Questions}

The crucial questions to be answered in this study are:

\subsubsection{Main Questions}

a) Is organizational politics a determinant of corporate governance configuration in the Nigerian Banking sector?

b) How is leadership effectiveness/ineffectiveness in the Nigerian Banking sector affected by organizational politics?

\subsubsection{Subsidiary Questions}

a) How is organizational politics expressed in the Nigerian Banking sector?

b) Is crime of obedience, which is an element in organizational politics, a catalyst which acts on/trigger the elements in corporate governance?

c) To what extent are the functional consequences of organizational politics responsible for leadership effectiveness and hence good corporation governance?

d) To what extent are the dysfunctional consequences of organizational politics responsible for leadership ineffectiveness and hence poor corporate governance?

\section{Literature Review}

In this study, leadership is central. The definition of the concept is therefore prudent. Leadership is a complex and subjective matter involving individuals in a complex web of relationships within complex organizations. It raises complex issues that have long been the subject of vigorous debate in the academic literature (Sonsino, 2002). The Anglo-Saxon etymological origin of the words lead, leader and leadership is 'læd', which means 
"path" or "road". The verb 'læden' means "to travel” (Gill, 2009). While Kets de Vries, Vrignaud and FlorentTreacy (2004) defined leader as one who shows fellow travellers the way by walking ahead (Kets de Vries, Vrignaud \& Florent-Treacy, 2004), Pratch and Jacobowitz (1997) posits that leadership is the process of influencing small group activities towards setting goals and attaining them. Within this context, Pratch and Jacobowitz argue that the leader function to direct the activities of the subordinates and motivate them to carry out their duties effectively. The position of Pratch and Jacobowitz is congruent with similar views expressed by Kotter (1998) who suggest that leadership is the process of moving a group or groups in some direction through mostly non-coercive means. The position of Kotter with regard to the element of coercion in leadership definition is not absolute as contingency theories suggest that there is no one best style of leadership. According to Gill (2009), successful and enduring leaders use different styles according to the nature of the situation and followers. While individuals may look to a leader to frame and concretize their reality, they may also react against, reject or change the reality thus defined (Smircich \& Morgan, 1982). While leadership often emerges as a result of expectations projected on the emergent leader by the led, the surrender of power involved provides the basis for negation of the situation or context created. Much of the tension in leadership stems from this source. Although leaders draw their power from their ability to define the reality of others, their inability to control completely; since its power is not absolute, provides seeds of disorganization in the organization of meaning they provide. Thus, if the leaders want to retain their role, they must respond to the needs of the followers as it is difficult to clap with one hand. As stated by Keith and Blomstrom (1971), in the long run, leaders who do not use power in a manner considered responsible by its constituency will lose it. That is the iron law of responsibility. Since leadership is exercised within the context of power/organizational politics, the concepts will be examined in the next section.

\subsection{A Perspective on Organizational Politics and Power}

According to Greenberg and Baron (1997), organizational politics are those actions not officially approved by an organization taken to influence others with a view to furthering personal goals.

Organizational politics and power are sometimes used interchangeably. The difference between the two concepts has never been fully settled. As stated by Pfeffer (1981), organizational politics is "study of power in action". Pettigrew (1973), described organizational politics as the use of power to influence decision making. Pfeffer (1981), defines political behaviour as "activities taken within the organization to acquire, develop and use power and other resources to obtain one's preferred outcomes in a situation where there is uncertainty or dissensus about choices". Eisenhardt and Bourgeois (1988) define organizational politics as observable, but often covert actions by which executives enhance their power to influence a decision.

Parsons (1960) noted the collective aspect of power, whereby persons in co-operation can enhance their joint power over third parties or over nature. As stated by Clegg (1989), in an attempt to fulfill or maintain their situated interests, agents enroll others into facilitating their projects through the manipulation of available network of power, social relations, drawing on existing repertoires, validation processes and disciplinary mechanisms. The position of Clegg (1989) is supported by Long (1992), who argued that agents and agencies reified by others as holding power and possessing knowledge enrol others into their projects more effectively than those imagined to be powerless and ignorant. Hayward and Boeker, (1998) and Maitlis, (2004), found that the position of a stakeholder is not static within the power dynamics of an organization. Mitchell, Agle and Wood (1997) characterized stakeholders who lack power but who have urgent and legitimate claims as "dependent", because they depend upon other stakeholders or the firm's managers for the power necessary to carry out their will. By definition, a stakeholder exhibiting both power and legitimacy will be a member of a dominant coalition. For example, in 2010, the Principal Managers and senior Managers in Union Bank, who were dependent stakeholders became active members of the Association of Senior Staff of Banks, Insurance and Financial Institutions in order to acquire power with a view to becoming definitive stakeholders. The act of collective organizational alliance alone is inadequate to overcome an organization of power. In order to produce an effective resistance, people must acquire the ability to activate a collective organization through outflanking. As stated by Gaventa (1980), those who possess the organizational advantage will always succeed in overcoming those who lack organizational resources, by means of organizational outflanking. Organizational outflanking finds expression in the ability to eliminate resistance with relative ease, to prevent them in advance by means of organizational priority, as well as to impose the order desirable to those doing the outflanking.

Although power is de-centred and ubiquitous in organizations, its distribution which is tied to resource is not even (Gaventa \& Cornwall, 2001; Handy, 1996). As stated by Handy and Clegg (1996), every organizational actor has the ability and discretion to make use of power, although given that power is not equally distributed, some members have more influence than others. For example, while the Managing Director / Chief Executive 
Officer can transfer a radical union leader/employee who fail to conform to a remote outpost, the union leader/employee may not have the capacity to effect the transfer of the Managing Director / Chief Executive Officer. Organizational political dynamics are therefore characterized by a constant battle between actors in privileged/subordinated roles within power relationships (Clegg, 1989). As a result of access to resources, the leadership within the context of study occupy a vantage position to determine "who gets what, when and how and who gets left out and how, through the instrumentality of political actions (Bachrach \& Baratz, 1962; Bachrach \& Baratz, 1998; Foucault, 1977). In the next section these prevailing political actions will be examined.

\subsection{Political Actions in the Nigerian Banking Sector}

There are three segments of organizational politics. These includes, political actions by individuals, leadership and leadership/individuals.

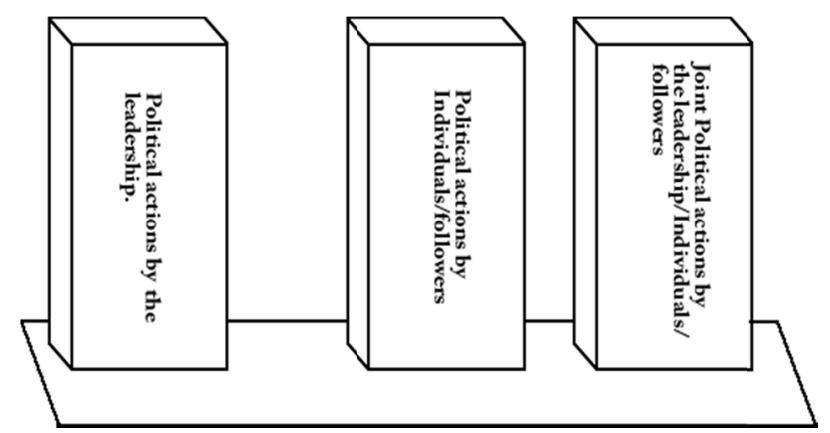

Figure 1. Organizational politics foundation pillars

\subsubsection{Political Actions by Individuals}

Lack of action or going along to get ahead (Kacmar \& Carlson, 1997; Feris \& Kacmar, 1992). Making friends with power brokers, self-promotion, deliberately withholding useful information, highlighting other people's errors and flaws, delaying tactics to block others, misinformation to confuse others, spreading false rumours to undermine others and keeping dirty files to blackmail others (Buchanan, 2007). Joining a coalition, whistle blowing, spreading rumours, leaking confidential information about the organization to the media, obstructing organizational policies or decisions through inaction or excessive adherence to rules, lobbing on behalf of or against a particular individual or decision alternative (Robbins \& Judge, 2009; Pettigrew, 1973). Private attempts to co-opt or lobby key executives, formation of insurgency groups (Bourgeois \& Eisenhandt, 1987, 1988). By passing the chain of command to gain approval (Ferris, Frink, Galang, Zhou, Kacmar, \& Howard, 1996). Taking of underserved credit, scape goating and blaming others, unfairly tarnishing the reputation of others, giving insincere flattery and telling people what they want to hear (Betof \& Seldman, 2006; Seldman \& Betof, 2004) are political actions by individuals.

\subsubsection{Political Actions by the Leadership}

Building network of useful contacts, using key players to support initiatives, making friends with power brokers, bending the rules to fit the situation, breaking the rules to achieve objectives, conceding minor issues to win major goals, compromising now to win future favours, using social setting to discover opinion, using others to deliver bad news (Buchanan, 2007), Termination of employment (Ogbuile, 2014). Developing contacts outside the organization through political, social and professional activities (Robbins \& Judge, 2009). Agenda control (Pettigrew, 1973), Deliberately undermining the effectiveness of a unit in order to displace a less favoured incumbent through appointing the wrong managers, starving businesses of resources for worthwhile projects, encouragement of wasteful investment and pressing for inappropriate targets (Campbell, 2003). Development of high level interaction, reward for members of in groups, in formal management of ingroups and formal management of outgroups, involvement of ingroups in decision making (Grean, 1976; Liden \& Graen, 1980; Andrews \& Kacmar, 2009; Wayne, Liden \& Sparrowe, 1994). Blocking of Union Leaders Access to emails (Union Bank Association of Senior Staff, 2011). Proscription of Trade Union (Omar, 2011, 2010; Osibodu, 2011). Transfer of Union leaders and employees who hold critical views about the leadership to unfavourable locations (Ferris, Frink, Galang, Zhou, Kacmar, \& Howard, 1996; Parker, Dipboye, \& Jackson, 1995). Punishing people who criticize or challenge ideas (Seldman \& Betof, 2004; Buchanan, 2007). Favouritism, transfer of 
favoured employees to favourable locations, creating favourable image, reward, (Buchanan, 2007). Use of Tribalism to weaken workers solidarity (Lukes, 2005), Accepting insincere flattery (Observation by the researcher), Internal and external alliances (like legitimization of a viewpoint through alliance with external consultants (Bourgeois \& Eisenhardt, 1998). are political actions exploited by the leadership.

\subsubsection{Political Actions Exploited Jointly by Individuals and the Leadership}

Making friends with power brokers (Buchanan, 2007), Lobbying on behalf of or against a particular individual or decision alternative (Robbins \& Judge, 2009), Developing contacts outside the organization through political, social and professional activities (Robbins \& Judge, 2009), Gaining and developing support, association with influential individuals, forming powerful coalitions, covert manipulations and formation of ingroups (Buchanan, 2007; Pettigrew, 1973), are political actions jointly exploited by individuals and the leadership.

There is a link between crime of obedience and organizational politics. The concepts will be examined in the next section.

\subsubsection{Crime of Obedience}

Crimes of obedience are acts considered illegal or immoral by the larger community, which are performed in response to orders from an authority (Kelman \& Hanilton, 1989). As a result of the distribution of advantages, cronies are appointed into important positions in the organization by the leadership. The appointed cronies only serve the interest of their principals. Thus, the crime of obedience is institutionalized and the objective of monitoring, control and independence that are vital in the promotion of good corporate governance are subverted and reduced to position of inessentiality. Although the crime of obedience is an element in organizational politics, it is a catalyst which triggers/acts on the elements of monitoring, independence and control in corporate governance.

\subsubsection{The Elements in Corporate Governance}

There are three elements in corporate governance in the Nigerian banking sector. These includes, Independence, Monitoring and Control (See Figure 2).

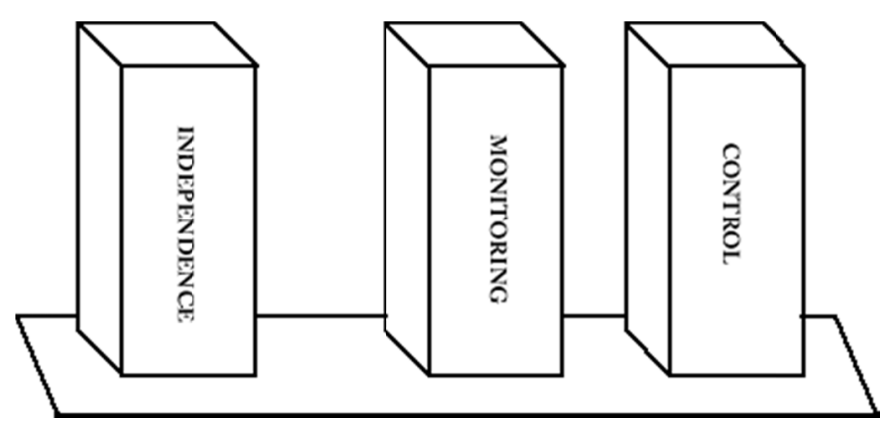

Figure 2. The corporate governance foundation pillars

A firm cannot function unless its various structural components are appropriately assembled (Chandler, 1962). Flowing from the position of Chandler, corporate governance will not achieve its purpose unless the elements of independence monitoring and control in corporate governance are properly assembled. As argued by Griffin and Pustay (1996), Independence and monitoring are achieved through organizational design. According to Griffin and Pustay, organizational design is the overall pattern of structural components and configurations used to manage the total organization. As stated by Jones (1995), through organizational design, organizational resources are allocated, tasks are assigned and employees are instructed about rules, procedures and expectations about job performances. Control is the process of monitoring and regulating activities in a firm so that targeted measure of performance is achieved (Anthony, 1988).

According to Anthony, the control process begins with the establishment of a goal or other performance target. Managers then monitor progress towards meeting that goal or target and take appropriate actions to keep the firm on track. There is a nexus between monitoring, independence and control in corporate governance. Jacoby (2005), define corporate governance "as structures and systems of control by which managers are held accountable to those with legitimate stakes in an organization". The extent of monitoring by the board is a function of the board's independence (Hermalin \& Weisbach, 1998; Becht, Bolton, \& Röell, 2005). As argued by 
Becht, Bolton and Röell (2005), the logic of independence is flawed as independent directors are dependent on the CEO for appointment and re appointment. According to Becht, Bolton and Röell, in spirit, most charters are meant to operate like a "Shareholder democracy", where the shareholders constitutes themselves into the electorate responsible for the election of the directors, with the CEO as the executive branch of government and the Board as the legislative branch. Becht, Bolton and Röell, posits that in firms with dispersed share ownership, the board is more of a "rubber stamp assembly", than a truly independent legislature responsible for checking and balancing the power of the CEO. This perspective is supported by Steiner and Steiner (2006), who found that while in theory, the flow of authority in an organization is from the powers granted in the Charter to Stockholders, then to directors, and then to the CEO, in reality in many corporations, the flow of authority is from the Charter to the CEO, who exercise power over directors, Shareholders and the public have limited ability to influence the activities of the directors or the CEO. Principal 6 of Basel Committee on banking supervisions, principles for enhancing Corporate governance (2010), provide that internal controls are instituted with a view to ensuring that banks are in compliance with applicable laws and regulations, reasonable checks on the discretions of management and employees to prevent them from exceeding their authority and perpetuation of fraud.

Levine (2004) examined further the external/government dimensions of control. According to Levine, while government policies that ameliorate the adverse effects of information and transaction costs can improve the governance of banks and enhance social welfare, bankers can exert a powerful influence over governments and regulators, so that regulations serve to promote the interest of incumbent bankers rather than promote social welfare and corporate governance. Rather than exerting a "helping hand" to ease market failures, governments may instead use a "grabbing hand" to satisfy political objectives (Shleifer \& Vishny, 1998). Politicians and regulations may induce banks to divert the flow of resources to politically connected ends or powerful banks may "capture" politicians and induce official regulators to act in the best interests of banks rather than in the best interests of society (Becker \& Stigler, 1974). For example, the intervention of Central Bank of Nigeria (CBN) in some banks in Nigeria in 2009 was motivated by the Regulatory Authority desire to protect the interest of champions of hostile take overs at the expense of existing shareholders. The intervention of CBN attracted the attention of the Public and the House of Representatives. As stated in House Resolution No. HR 70/2012 (2014), "The CBN refused to produce the special examination preceeding its intervention in 10 banks", including Union Bank. "Although the requirement for special examination is a provision in Section 33 of Banks and other Financial Institutions Act, 2004; an Act of the National Assembly, the CBN argues that the reports, among many others which the House requested is purely confidential to it alone.... it is strongly felt that the CBN appears to have too many things to hide. This is a great danger to the economy".

Levine (2004) suggests that direct official supervision of banks may actually reduce the efficiency of corporate governance of banks (Levine, 2004), Barth, Caprio and Levine (2004) found that regulatory power is positively associated with national levels of corruption and negatively associated with overall levels of bank development. To constrain the negative impact of regulation on corporate governance, the mechanism to negate the "grabbing hand" of politicians and regulators must be created. There must also be incentives for official agencies to improve social welfare (Shleifer \& Vishny, 1998; Haber, Razo \& Maurer, 2003). One approach to improving corporate governance is the alignment of the interest of the regulators with the society through the creation of an independent agency with a well-defined objective. This is predicated on the argument that the regulation that empower private monitoring increase the effectiveness of the corporate governance of banks. Where the supervisory agency is independent from banks and supervisors have proper incentives, the probability that the banks will capture supervisors will diminish (Levine, 2004). Barth, Caprio and Levine (2004), posits that the independence of the supervisory agency reduces the pernicious effects of a powerful regulatory agency. In a related arguments, Levine (2004), suggest that "broad national institutions, such as the openness and competitiveness of the political system or effectiveness of the media, influence the effectiveness of corporate governance in banks". As stated by Levine, closed and uncompetitive political systems provide greater scope for political and regulatory capture. According to Levine, where the media is corrupted/influenced by banks, the media is unlikely going to be helpful in exposing insidious management actions which impair corporate governance. Evidence tends to support the view that regulations that empower the private sector work best to improve the governance of banks (Levine, 2004). Barth, Caprio and Levine (2004) "Construct a measure of the degree to which regulations empower the private sector. This measure includes information on regulations that force banks to disclose information to the public and impose severe penalties on a bank's directors or officers for providing inaccurate or misleading information”. Barth, Caprio and Levine suggest that strong private empowerment boost overall bank development and efficiency and reduces the reliance on corrupt ties with bank officials. 
The role of employees or their representatives in the enhancement of good corporate governance is recognized under the OECD Principle of corporate governance. As stated in OECD Principles of Corporate governance (2008), "Unethical and illegal practices by corporate officers may not only violate the rights of stakeholders but also be to the detriment of the company and its shareholders in terms of reputation effects and an increasing risk of future financial liabilities. It is therefore to the advantage of the company and its shareholders to establish procedures and safe harbours for complaints by employees, either personally or through their representative bodies, and others outside the company, concerning illegal and unethical behaviours". To enable employees or their representatives maintain their institutional identity, their right to hold alternative views is imperative. Whistle blowing, which is within the rubrics of political behaviour, is one of the medium for achieving this (Robbins \& Judge 2009). To enable employees and their representatives act as enablers of corporate governance, their ability to constrain the ability of management to act arbitrarily must be acknowledged.

In the Nigerian banking sector, the role of employees or their representatives as enablers of corporate governance receive very scanty attention as the leadership is unwilling to respect alternative views and submit itself to monitoring. Besides, the belief that employees are only to accept orders and not heard is still fashionable. Kashyap, Rajan and Stein (2008) and Cohen, Jeffrey, Krishnamoorthy, Ganesh, Wright and Arnie (2009), document that unless management allows itself to be monitored; the substance of governance activities will be subverted. The role of employees and their representatives in the enhancement of good corporate governance should be given further meaning through concentrated share ownership by employees. This will assist in mitigating the negative impact of large informational asymmetries and enormous discretion over the flow of information by managers. The attainment of this goal and a synergy between employees and their representatives and strong private empowerment regulation will enhance good corporate governance in banks.

\subsubsection{Organization Politics /Corporate Governance and Leadership Effectiveness/Ineffectiveness}

Feidler (1967) asserts that it is simply not meaningful to speak of an effective leader or an ineffective leader. As argued by Feidler, we can only speak of a leader who tends to be effective in one situation and ineffective in another. The effectiveness, of a particular style of leadership depends on the relationship between the characteristics of the leader, the followers and the situation. To Fiedler (1967), the effectiveness of a leadership style, either task oriented or people oriented, depends on the situation in terms of how defined and structured the work is; how much position power (authority) the leader has and the relationship between the leaders and the followers. Barrow (1977), found that the propensity to express leadership findings in binary terms of effective/ineffective hamper the understanding of leadership effectiveness. This perspective is supported by other researchers who expressed concern about the practical relevance and utility for the determination and distinguishing between "good" or "bad" managers. According to them, there is little agreement about what constitutes managerial effectiveness (Luthans, Rosencrantz, \& Henressey, 1985; Martinko \& Gardner, 1990, Cammock, Nilakant, \& Dakin, 1995; Willcocks, 1992;). The argument against the expression of leadership in effective/ineffective binary is weak as leadership is only a means to an end. Besides, the practical essence of leadership will be reduced to inessentiality if its outcome cannot be measured in binary terms of effective/ineffective. Leader behaviour as dependant variable seeks to discover how certain situation influences behaviour and the degree of variability in leadership behaviour. The optimal behaviour pattern for a leader in a given situation is yet to be discovered (Yukl, 1989). Stogdill (1974) in an earlier study found that while certain traits such as "being creative" or "persuasive" may help one become an effective manager, it cannot explain the factor behind success in every situation. According to those who have studied managers, the effective ones engage in a variety of management-oriented behaviours (Quinn, 1999; Yukl, 1989). Previous research has attempted to identify what those behaviours responsible for success are (Bernardin \& Beatty, 1984). Since organizational politics is within the rubrics of behaviour there is therefore a link between organizational politics and leadership effectiveness/ineffectiveness (Boleman \& Deal, 1997, 1992, 1991).

\section{Research Methodology}

This study reflects the stance of interpretivism/constructionism. Within interpretive approaches, the human world is never a world in itself; it is always an experienced world; that is, a world that is always related to a conscious subject. Thus, the ontological and epistemological assumptions underlying the interpretive research tradition reject the existence of an objective knowable reality beyond the human mind. Instead, they stipulate that knowledge is constituted through lived experience of reality (Sandberg, 2005). Instead of assuming an objectivist epistemology for the existence of objective reality, advocates of interpretive approaches typically claim that reality is socially constructed by continuous negotiation between people about the very nature of that reality.

As a result of my dual role as a researcher and a stakeholder in the institution under study, I will play a part in the 
research process. It will be impossible for me to carry out this investigation without being involved. In order for me to understand the subjective meaning of the impact of organizational politics and corporate governance on leadership effectiveness/ineffectiveness, I will be immersed in the research context.

\subsection{Research Strategy}

The ontological and epistemological approach adopted by a researcher, has direct impact on research strategy. As stated by Christoe, Valachis and Anastasiadou, (2005), interpretevists are more liable in using action research. The adoption of action research in this study is therefore predicated on this premise. As Kemmis and McTaggart (1988) stated, "..... to do action research is to plan, act observe and reflect more carefully, more systematically, and more rigorous than one usually does in everyday life; and to use the relationships between these moments in the improvement of knowledge".

\subsubsection{Research Methods}

Within case study, different methods can be used, which are traditionally interviews, observations, and documentary analysis. On the choice of methods, Robson (2000) stated: "There is 'no best method' but the choice should be according to the feasibility of time and resources. The reason behind choosing multi-methods, in collecting data, is that every method has strengths as well as weaknesses, and matching the strengths of one with the weaknesses of another could help in later stages of the study".

My choice of 'multi-methods' in this study relates to the issue of validity. According to Morse Barret and Mayan, (2002) “...to validate is to investigate, to check, to question, and to theorize. All of these activities are integral components of qualitative inquiry that ensure rigor. Whether quantitative or qualitative methods are used, rigor is a desired goal that is met through specific verification strategies. While different strategies are used for each paradigm, the term validity is the most pertinent term for these processes"

Hitchcock and Hughes (1995) argued that: “...validity has to do with instruments/techniques, data, findings and explanation... Is the choice of data collection techniques or instruments suited to the type of data required and research questions formulated? - the notion of 'fitness for purpose'... The notion of validity checks suggests that, there are things which the researcher can do to increase validity. The most common way in which validity can be strengthened is by some form of triangulation or diversity of methods". Another initial consideration in validity is to engage in piloting before the formal research period. According Robson (2000, pp. 164-165) "It may be that there is only one case to be considered, or there are particular features of the case selected (such as geographical or temporal accessibility, or your own knowledge of the case), such that there is no sensible equivalent which could act as the pilot". In this study my own knowledge of the Nigerian banking sector was felt sufficient not to necessitate pilot studies.

\subsubsection{Interviews}

My interviews were non-standardized (Hitcheock \& Hughes, 1995). I used only informal interviews and conversations, with individuals and groups.

There were many opportunities for informal interviews or conversations with different participants. Hitchcock and Hughes (1995) clarified that: “...Conversations are, of course, a major element in any kind of field research. Conversations not only constitute an important source of data but might also be regarded as a method of research in their own right". The informal meetings with some key Stakeholders constituted such 'conversations'. As a result of the prevailing dictatorship in the Nigerian banking sector, obtaining direct response to my questions from one of the former MD/CEOs of Union Bank was futile. To enable me obtain the relevant response from the key informant, a heavier jolt was required. To accomplish the objective, I sent a petition to the House of Representatives, Banking and Currency Committee, through the International Centre for Corporate governance and Conflict studies (ICCGCS); a non-governmental organization, with the raison d'être of holding corporate leaders accountable. On the $21^{\text {st }}$ of Nov. 2013, a public hearing took place in furtherance of my petition. I made written and oral presentation at the public hearing. The responses of one of the former $\mathrm{MD} / \mathrm{CEO}$ of Union Bank to my petition are relied upon in this enquiry.

\subsubsection{Observations}

As a result of my dual role as a researcher and an employee in the research context, I will play a part in the research process. It will be impossible for me to carry out this investigation without being involved. In order for me to understand the subjective meaning of the impact of corporate governance and organizational politics on leadership effectiveness/ineffectiveness, I will be immersed in the research context. I observed directly the dynamics of organizational politics and corporate governance within the context of study. The importance of observation and its link to validity was summarized by (Gillham, 2000) when he stated that "The overpowering 
validity of observation is that it is the most direct way of obtaining data. It is not what people have written on the topic. It is not what they say they do. It is what they actually do". This provided the insight into what people 'actually do', or for my case, 'actually talk about' in certain settings (Griffins, 1985).

\subsubsection{Documentary Analysis}

Documents that were scrutinized included: letters from the Management and Trade Unions, Emails, Circulars, Internal Memos, minutes of meetings. With regard to informal conversations, I made notes about them from memory as soon as possible. I compared the documents obtain vertically. By comparing them vertically I mean; the theoretical content with the practice on ground.

\subsubsection{Data Analysis}

The key points for interpretivism is that reality is socially constructed. The task before us is to identify what meanings people place on events or "occurrences" in order to explain their reactions to such occurrences. This shows people as actively constructing their context (Gidden, 1993). Gage (1989) wrote "interpretive researchers regard individuals as able to construct their own social reality, rather than having reality always be the determiner of the individuals' perception". Interpretivist research is able to extract such meanings and through the researchers' own interpretations attempt to establish the different versions of "reality" through the participants' eyes. This is particularly important in a study which looks at political actions in the Nigerian Banking Sector. The narrative method shall be employed in analyzing the qualitative data relating to research. As stated by Riessman (2002) narrative analysis seeks to put together the "big picture" about experiences or events as the participants understand them. Narrative analysis focuses on "the story itself" and seeks to preserve the integrity of series of events.

\subsubsection{Study Population}

A research population is a well-defined collection of individuals or objects with similar characteristics. All individuals or objects within a certain population usually have a common, binding characteristics or trait (Malthus, 1798). According to Rosset (1987), a sample is a subset of the population. The concept of sample arises from the inability of researchers to test all the individuals in a given population. The sample must be representative of the population from which it was drawn and it must have a good size to warrant analysis. Purposive sampling is adopted in this study as Union bank of Nigeria Plc is the research context. As stated by Saunders, Lewis and Thornhil (2003) "Purposive or judgmental sampling enables you to use judgment to select cases that will best enable you to answer your research question(s) and to meet your objectives". According to Neuman (2000), purposive sampling is often used when working with small samples such as a case study and when you wish to select cases that are particularly informative. Elslon (1994) posits that sound conclusion can always be drawn from the quantitative sample size population of informed practitioner on a given subject. This study will therefore rely on the following "core informants": for face to face interview:

- The Managing Director/Chief Executive Officer, Union Bank of Nigeria Plc.

- $\quad$ Two former Managing Director/Chief Executive Officer, Union Bank of Nigeria Plc.

- $\quad$ Two former Directors, Union bank of Nigeria Plc.

- General Secretary, Union Bank association of Senior Staff.

- General Secretary, Union Bank Pensioners Association.

- 27 National Executive Council Members: Union Bank Association of Senior Staff.

- President: Progressive Shareholders Association of Nigeria.

- $\quad$ Five Ex Employees of Union Bank of Nigeria Plc.

- $\quad$ Five Ex Employees of Union Bank of Nigeria Plc.

- An Employees of Union Bank Finance Services Department.

- A Secret Agent of Union Bank of Nigeria Plc.

\subsection{The Conceptual Framework}

As depicted on the conceptual framework there is a nexus between organizational politics, crime of obedience, corporate governance and leadership effectiveness/ineffective and corporate performance. 


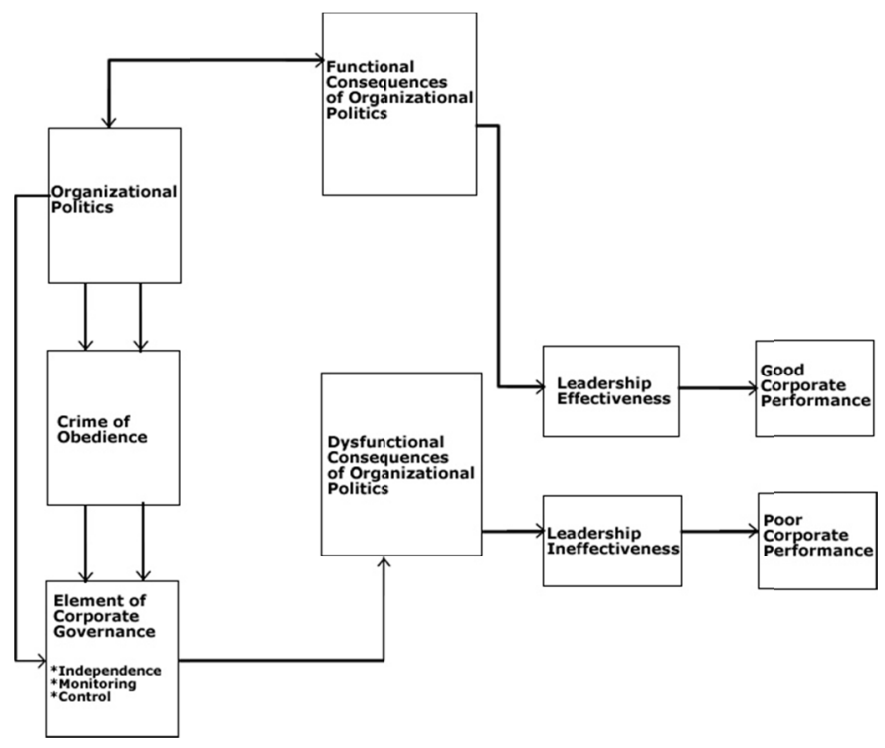

Figure 3. Conceptual framework

Although the crime of obedience is an element in organizational politics, it is viewed as a catalyst which triggers/acts on the elements in corporate governance. As shown in Figure 3, as a result of crime of obedience, the elements of control, monitoring and independence in corporate governance are subverted, culminating in ineffective leadership and poor corporate performance. The conceptual framework also demonstrates the existence of functional and dysfunctional consequences of organizational politics. While the functional consequences of organizational politics will enhance leadership effectiveness and hence good corporate performance, the dysfunctional consequences will impair leadership ineffectiveness and hence poor corporate performance.

\section{Key Findings and Implications}

This section presents key findings of the research and how they correlate or otherwise with previous research. The findings are presented below:

\subsection{Organizational Politics Prevails in the Nigerian Banking Sector}

The political actions by individuals, the leadership and political actions exploited jointly by the leadership and individuals were found as the three segments of organizational politics in the Nigerian banking sector. The political actions by individuals triggers political actions by the leadership.

4.1.1 Organizational Politics as a Determinant of Corporate Governance Configuration and Crime of Obedience as a Catalyst which Triggers the Elements in Corporate Governance

The crime of obedience are acts considered illegal or immoral by the larger community, which are performed in response to orders from an authority (Kelman \& Hamilton, 1989). Although the crime of obedience is an element within organizational politics, it is a direct consequence of the manifestation of organizational politics. In furthering the political action of distribution of advantages, the objective of monitoring, independence and control instituted for the enhancement of corporate governance are subverted in the Nigerian banking sector.

4.1.2 The Leadership in the Nigerian Banking Sector, Pay Lip Service to the Development of Good Corporate Governance

Corporate governance is yet to serve its purpose in the Nigerian Banking sector as emphasis has been on looking at issues of independence and disclosure. The management in the Nigerian Banking sector acts arbitrarily. While they refuse to submit to monitoring, crime of obedience and promotion of individuals to position of incompetence abound. This perspective is supported by Sanusi (2010), the then Governor of Central Bank of Nigeria, when he stated that "Some banks in Nigeria are only paying "lip service" to compliance with most sections of the corporate governance code". In the Nigerian banking sector, the role of employees or their representatives as enablers of corporate governance receive very scanty attention as the leadership is unwilling to respect alternative views. Besides, the belief that employees are only to accept orders and not heard is still fashionable. Kashyap, Rajan and Stein (2008) and Cohen, Jeffrey, Krishnamoorthy, Ganesh, Wright and Arnie 
(2009) document that unless management allows itself to be monitored; the substance of governance activities will be subverted.

\subsubsection{The Central Bank of Nigeria as a Regulator Is Captured by Some Regulated Banks}

The development of corporate governance in the Nigerian banking sector is constrained as a result of the capture of Central Bank of Nigeria by the leadership of some banks. The CBN acts as mere proxy to some banks and other external interests.

\subsubsection{Dictatorship in the Nigerian Banking Sector}

There is dictatorship in the Nigerian banking sector. In Union bank, as a result of awareness that the potency of the ability of employees and their representatives to constrain the ability of the management to act arbitrarily is enhanced through concentrated share ownership, the voting rights of employees and their representatives at the Annual General meetings is now withdrawn and the voting right thereof exercised on their behalf by the leadership of the Bank.

\subsubsection{There Are Some Functional Consequences of Organizational Politics}

The breeding of cynics who may be more likely to speak out against unprincipled behaviours of organizational decision makers (Dean, Brandes \& Dhwardkar, 1998; Andersson \& Bateman, 1997; Anderson, 1996) and creativity which sprouts from frustration (Collins \& Porras, 2002), were found as the functional consequences of organizational politics. The attainment of independence, monitoring and control in corporate governance in the Nigerian banking sector activates the functional consequences of organizational politics.

\subsubsection{There Are Dysfunctional Consequences of Organizational Politics}

The constraining of the elements of independence, monitoring and control in corporate governance culminates into dysfunctional consequences of organizational politics. The dysfunctional consequences of organizational politics results in the inability to develop a high-performing organization (Valle \& Witt, 2001; Yukl, 1989) and loss of strategic position by some banks in Nigeria (Buchanan, 2007).

\subsubsection{Convergence between Leadership Effectiveness and Leadership Ineffectiveness}

In this research I found that while the functional consequences of organizational politics enhance leadership effectiveness, the dysfunctional consequences of organizational politics resulted in leadership ineffectiveness. There is however a paradox in my findings as leadership ineffectiveness which constrains leadership effectiveness resulted in leadership ineffectiveness. In this study, leadership ineffectiveness is captured in terms of employees dissatisfaction, labour turnover, injury, loss of valuable lives, frauds, decline in profitability and growth in operating expenses (Muldrow, Buckley, \& Schay, 2002).

\subsubsection{Leadership Ineffectiveness Contributes to Poor Corporate Performance}

The ineffectiveness of the leadership at the process stage resulted in poor corporate performance of the Nigerian banking sector. As a result of the punitive transfers of employees, pushing out and humiliation of competent employees who challenge the leadership; vital human capital required for the growth and development of the banking sector are lost. As stated by Collins (2009), "when an organization grows beyond its ability to fill its key seats with the right people, it has set itself up for a fall".

\subsection{Discussions and Model Building}

This section looks at discussions leading to the building of organizational politics, corporate governance, and leadership effectiveness/ineffectiveness and good corporate performance/poor corporate performance model. The model will establish a connection between organizational politics, corporate governance, leadership and corporate performance. There are three stages in the model building-The input stage, process stage, and the output stage as presented in figure 4 


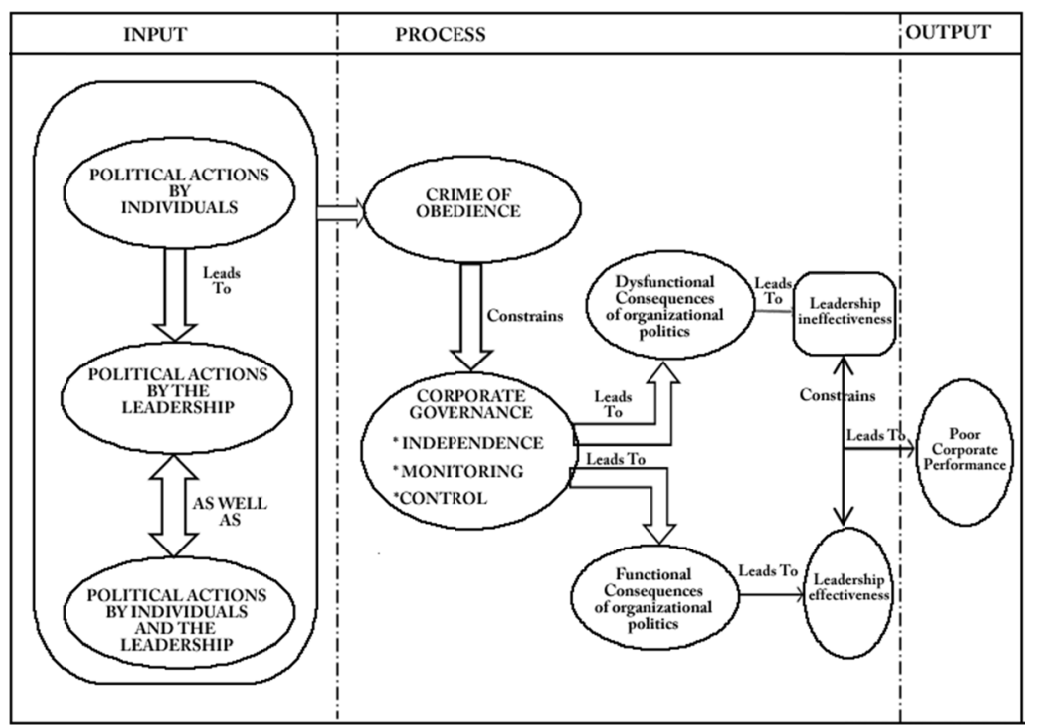

Figure 4. Organizational politics, corporate governance, leadership effectiveness/ineffectiveness and corporate performance model

Adapted from: Huxham, C. and Vangen, S. (2003).

\subsubsection{Input Stage}

The input segment includes, political actions by individuals, the leadership as well as political actions jointly explored by individuals and the leadership. In the conceptual framework, the political actions by individuals, leadership and political actions explored by individuals and the leadership were not separated. In the model however, they are segmented in line with the argument of research participants. There is an agreement between the framework and the model that political actions generally, motivates the crime of obedience which is within the rubrics of organizational politics. According to Gillhan (2000, p. 46), "The overpowering validity of observation is that it is the most direct way of obtaining data. It is not what people have written on the topic. It is not what they say they do. It is what they actually do". I observed that political actions by individuals, acted as enabler of institutionalized political actions by the leadership. An observed comment following a conversation between employees as stated below will confirm this:

We are the ones killing ourselves. We sold ourselves to the management. When the managing director came, she did not know anybody. Some employees went and told her lies about other employees in exchange for favour.

Gage (1989, p. 5) wrote: "interpretive researchers regard individuals as able to construct their own social reality, rather than having reality always be the determiner of the individual's perception".

\subsubsection{The Process Stage}

In the input stage, political actions by individuals leads to political actions by the leadership. Political actions by individuals and the leadership as well as political actions jointly explored by individuals and the leadership leads to crime of obedience which constrains the elements of independence, monitoring and control in corporate governance. This perspective corresponds with the framework in Figure 3 where the crime of obedience was identified as the catalyst which triggers/acts on corporate governance configuration. The crimes of obedience are acts considered illegal or immoral by the larger community, which are performed in response to orders from an authority (Kelman \& Hamilton, 1989). Although the crime of obedience is an element within organizational politics, it is a direct consequence of the manifestation of organizational politics. For example, in furthering the political action of distribution of advantages, the objective of monitoring, independence and control instituted for the enhancement of corporate governance are subverted. To achieve good corporate governance, the nexus between organizational political, crime of obedience and the elements of independence, monitoring and control in corporate governance must therefore be acknowledged.

\subsubsection{The Functional Consequences of Organizational Politics}

In this study, the breeding of cynics who may be more likely to speak out against unprincipled behaviours of organizational decision makers (Dean, Brandes, \& Dhwardkar, 1998; Andersson \& Bateman, 1997) and 
creativity which sprouts from frustration (Collins \& Porras, 2002), were the only functional consequences found in the context of research. As shown in Fig. 4, good corporate governance leads to functional consequences of organizational politics. This corresponds with the framework which stipulate that the attainment of independence, monitoring and control in corporate governance activates the functional consequences of organizational politics.

\subsubsection{The Dysfunctional Consequences of Organizational Politics}

As depicted in Fig 4, the constraining of the elements of independence, monitoring and control in corporate governance leads to dysfunctional consequences of organizational politics. This corresponds to the framework which stipulates that the constrain of the elements of independence, monitoring and control, in corporate governance through crime of obedience, activates the dysfunctional consequences of organizational politics. The dysfunctional consequences of organizational politics results in inability to develop a high-performing organization (YukI, 1989) and loss of strategic position by institutions (Buchanan, 2007).

\subsubsection{Leadership Effectiveness and Leadership Ineffectiveness}

As stated in the framework, while the functional consequences of organizational politics enhance leadership effectiveness, the dysfunctional consequences of organizational politics leads to leadership ineffectiveness. As shown in the model in Figure 4 leadership ineffectiveness which constrains leadership effectiveness results in leadership ineffectiveness.

\subsubsection{Output Stage}

The stage of corporate performance is stated in the output stage. The ineffectiveness of the leadership at the process stage leads to poor corporate performance. This corresponds with the framework where I stated that leadership ineffectiveness contribute to poor corporate performance. The punitive transfers of employees, pushing out and humiliation of competent employees who challenge the leadership as a result of organizational politics will only promote poor corporate growth. In an interview, an employee in Union Bank said:

Things are going from bad to worse; the good hands are being pushed out of the organization, while the bad and inexperienced hands that are willing to conform are retained. No organization can be more efficient that the quality of its workforce.

The perspective of the above participant is valid as it is easier for the head of a camel to pass through the eye of a niddle than for an organization to grow beyond the competence of its workforce (Ahearn, Ferris, Hochwarter, Douglas, \& Ammeter, 2004; Collins 2009).

\subsubsection{Recommendations}

Improvement in leadership effectiveness/corporate performance is dependent on improvement is corporate governance and the mitigation of the negative impact of organizational politics. The attainment of these goals cannot be predicated on self-equilibrating mechanism. It must therefore be acknowledged that the applicability and transferability of a model is dependent on who and the context to which it is applied and whether it is acceptable for application. The development of organizational politics, corporate governance, leadership effectiveness/ineffectiveness and corporate performance model provides insight into corporate governance and leadership effectiveness in the Nigerian banking sector. It also highlights the importance of application of good corporate governance in the enhancement of corporate performance. Therefore, the recommendations outlined below will assist in mitigating the dysfunctional elements in organizational politics, enhance good corporate governance, leadership effectiveness and corporate performance.

\subsubsection{Institutionalization of Formality and Minimization of Informality}

Organizational political dynamics are characterized by a constant battle between actors in privileged/subordinated roles within power relationships (Clegg, 1989). As a result of access to resources, the leadership within the context of study, occupy a vantage position to determine "who gets what, when and how and who get left out and how, through the instrumentality of outflanking via certain political actions/elements (Bacharach \& Baratz, 1970; Foucault, 1977). The dysfunctional consequences of organizational politics should be mitigated through the institution of formality and minimization of informality by the leadership. As stated by Ferris, Frink, Galang, Zhou, Kacmar and Howard (1996), organizational politics are often enacted behind the scenes and typically occur in organizations where there are few rules and regulations to guide decision making. Examples include by-passing the chain of command to gain approval, going through improper channels to obtain special equipment, and lobbing high level managers just prior to decisions on promotions or transfer to more favourable locations. 
4.2.9 Cultivation of Strong Institutions with the Ability to Constrain the Ability of Management to Act Arbitrarily

The existence of mere codes will not promote the health of corporate governance. The attainment of good corporate governance in the Nigerian banking sector, is dependent on the development of strong institutions with the ability to constrain the ability of the leadership to act arbitrarily. To enhance good corporate governance, the role of employees or their representatives in the enhancement of good corporate governance must be recognized. As stated in OECD Principles of Corporate governance (2008), "Unethical and illegal practices by corporate officers may not only violate the rights of stakeholders but also be to the detriment of the company and its shareholders in terms of reputation effects and an increasing risk of future financial liabilities. It is therefore to the advantage of the company and its shareholders to establish procedures and safe harbour for complaints by employees, either personally or through their representative bodies, and others outside the company, concerning illegal and unethical behaviours". To enable employees or their representatives maintain their institutional identity, their right to hold alternative views is imperative. Whistle - blowing, which is within the rubrics of political behavior, is one of the medium for achieving this (Robbins \& Judge 2009). To enable employees and their representative act as an enablers of corporate governance, their ability to constrain the ability of management to act arbitrarily must be recognized.

\subsubsection{The Empowerment of Private Monitoring}

The Central Bank of Nigeria is now captured by some powerful banks. The regulatory agency is now acting as proxy to some powerful banks and other external principals. The ability of CBN to promote good corporate governance is now in doubt. The alignment of the interest of the regulators with the society through the creation of an independent private agency with a well-defined objective is now imperative. The empowerment of private monitoring through the institution of the independence of supervisory agency independent of banks and CBN will increase the effectiveness of corporate governance in the Nigerian banking sector.

\subsubsection{Synergy between Employees and Their Representatives and Private Sector Empowerment Regulation}

The role of employees and their representatives in the enhancement of good corporate governance should be given further meaning through concentrated share ownership by employees. This will assist in mitigating the negative impact of large informational asymmetries and enormous discretion over the flow of information by managers. The attainment of this goal and a synergy between employees and their representatives and strong private sector empowerment regulation will enhance effective corporate governance in banks.

\subsection{Implications for Further Research}

The process and findings of the research have exposed the fact that research into organizational politics, corporate governance and leadership effectiveness and corporate performance does not only search for problem descriptions and suggested measures for implementation, but strive to find further questions and problems due to the organizational dynamics and changing expectations and behaviors of stakeholders. This research does not end but stops at where there are further grounds for research. This is because there are areas that have not been explored and even some of the areas explored need further investigations. Suggested areas for further research are identified and presented below:

\subsubsection{The Application of Organizational Politics, Corporate Governance, Leadership} Effectiveness/Ineffectiveness and Corporate Governance Model

So far this study has succeeded in developing organizational politics, corporate governance, leadership effectiveness, ineffectiveness and corporate performance model and knowledge that are required to enhance leadership effectiveness with a view to enhancing corporate performance. This is the main contribution of this research. Notwithstanding this, the work opens up new area for research-understanding and application of the model in the banking sector for practical solution to the challenges of poor corporate governance, leadership ineffectiveness and poor corporate performance. This prepares the grounds for interesting research questions. The research could be in two areas as follows:

1) Comprehension of the model as a working tool.

2) The utilization of the model for effective and sustainable development of leaders in the Nigerian banking sector.

This is recommended especially as the model which found the nexus between organizational politics, crime of obedience, corporate governance and leadership effectiveness have not be used as methods of furthering corporate performance in the Nigerian banking sector . 


\subsubsection{Areas for Further Research}

A possible area of further research would be to investigate the strategies for mitigating organizational politics. The research could focus on key stakeholders in the Nigerian banking. It could also be generalized across other sectors. The aim and objectives of such a study could be determined with reference to the global economy.

The three main research questions could be:

1) What are the strategies for mitigating organizational politics in the Nigerian sector?

2) What is the impact of the mitigating of organizational politics on corporate governance?

3) How does the mitigation of organizational politics impacts on corporate governance, leadership ineffectiveness and corporate performance?

The research will further an understanding and establish the strategies required for the mitigation of organizational politics. It will also help companies to promote good corporate governance, leadership effectiveness and corporate performance.

\subsubsection{Research Limitations}

The context of research is the Nigeria banking sector. The developed model on organizational politics, corporate governance, leadership effectiveness/ineffectiveness and corporate performance may be less applicable to the other sectors of the Nigeria economy. The generalization of the model to the wider economy is therefore limited.

Another limitation is the inherent bias in the research. My own background, ideology and knowledge in the research could be understood in the light of my influence as someone who is informed of the research theme and the Nigerian banking sector.

Also the research spans over five years. Literature reviewed five years ago as basis for interview questions for data collection and analysis might have changed over this period. Therefore, the flows of questioning and data results could have been different if data collected were based on issues as they are today. Variables identified which influenced organizational politics, corporate governance and leadership could have produced different results. Furthermore, although, the techniques employed in data collection were carefully designed and fully followed; there is however a fundamental question about the reliability and validity of the data produced for analysis and findings. The crucial question blowing in the wind is, was data produced by interviewees and documentary evidence done reflections of organizational politics, corporate governance and leadership effectiveness/ineffectiveness in the Nigerian banking sector? There may be problems with data quality because there was the assumption that people were telling the truth. The question of reliability and validity of data is largely dependent on the integrity and objectivity of the interviewees. The reliability of data was therefore predicated on what the researcher was told by respondents and the interpretation of documentary evidence and the observation provided.

Lastly, the research is affected by the researcher's inexperience. However, during the five year period of the research, the researcher developed greater degree of knowledge. This means if the research is to be conducted today; the quality could be extremely improved. The research process has improved various aspects of the researcher's knowledge and skills; including literature review, data presentation and analysis, research design and presentation of findings which the researcher cannot have the chance to fully apply in this research. The findings could however be grounds for further research, which could impact positively on any identified shortfall.

\section{Conclusions}

In this study, the concepts of leadership, organizational politics, power and corporate governance were examined. The nexus between organizational politics, corporate governance and leadership effectiveness/ineffectiveness were explored. I found that there are functional and dysfunctional consequences of organizational politics. However, the convergence between effects of the functional and dysfunctional consequences of organizational politics culminates in leadership ineffectiveness. It is established in this research that organizational politics is a determinant of corporate governance configuration. The effectiveness of the leadership in the Nigerian banking sector is now constrained as a result of the collapse of independence, monitoring and control. As a result of crime of obedience, those who occupy sensitive positions who are products of distributed advantages/disadvantages only serve the interest of their principals. Thus, the objective of monitoring, independence and control instituted for the enhancement of corporate governance are subverted. Although the crime of obedience is within the rubrics of organizational politics, it is found in this study as a catalyst which triggers/acts on the elements in corporate governance. The Central Bank of Nigeria (CBN) failed woefully in 
acting on the exposed incongruities and corporate lawlessness that are impairing corporate governance in Union Bank. It is clear that CBN as a regulator is now captured by some regulated banks. The ability of CBN to act as an enabler of good corporate governance with a view to enhancing the performance of the Nigerian banking sector is in doubt. To enhance good corporate governance, $\mathrm{CBN}$ as a regulator must be regulated and watched closely. The desired change in corporate governance cannot rest on mere codes. It must be driven by strong institutions. To arrest the dictatorship in Nigerian banks which is exacerbating the sordid state of corporate governance, employees and their representatives and other strong institutions must be allowed to exist to constrain the ability of the leadership in the Nigerian banking sector to act arbitrarily. The role of employees and their representatives in the enhancement of good corporate governance should be given further meaning through concentrated share ownership by employees. The attainment of this goal and a synergy between employees and their representatives and strong private sector empowerment regulation will enhance effective corporate governance and corporate performance of banks.

\section{References}

Andrews, M. C., \& Kacmar, K. M. (2001). Discriminating and Organizational Politics, Justice, and support. Journal of Organizational Behaviour, 22, 351. http://dx.doi.org/10.1002/job.92

Anderson, L. M. (1996). Employee cynicism: An examination Using a Contract Violation Framework. Human Relations, 49, 1395-1418. http:dx.doi.org/10.1177/001872679604901102

Andersson, L., \& Bateman, T. (1997). Cynicism in the workplace: some causes and effects. Journal of Organizational Behavior, 18, http://dx.doi.org/10.1002/(SICI)1099-1379(199709)18:5<449::AID-JOB808>3.0.CO;2.0

Anthony, N. A (1988). The Management Control Function. Boston: Harvard Business School.

Ahearn, K. K., Ferris, G. R., Hochwarter, W. A., Douglas, C., \& Ammeter, A. P. (2004). Leader Political Skill

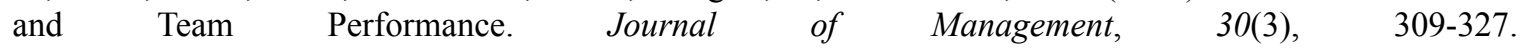
http://dx.doi.org/10.1016/j.jm.2003.01.004

Bacharach, S. B., \& Lawler, E. J. (1998). Political Alignments in Organizations: Contextualization, Mobilisation and Co-Ordination. In R. M. Kramer \& M. A. Neale (Eds.), Power and Influence in Organizations (pp. 67-88). Thousand Oaks, C. A: Sage.

Bachrach, P., \& Baratz, M. S. (1962). Two faces of Power. American Political Science Review, 56, 947-952. Retrieved from http://www.jstor.org/

Barrow, J. C. (1977). The variables of leadership: A Review and Conceptual Framework. Academy of Management Review, 231-245. http://dx.doi.org/10.5465/AMR.1977.4409046

Barth, J. R., Caprio, G. Jr., \& Levine, R. (2004). Bank supervision and regulation: What works best. Journal of Finanacial Intermediation, 13(2), 205-248. http://dx.doi.org/10.1016/j.jfi.2003.06.002

Berger, P. L., \& Luckman, T. (1966). The Social Construction of Reality. Harmondsworth, UK: Penguin.

Beerel, A. (2009). Leadership and change Management. Los Angels: Sage Publications LTD.

Becker, G., \& Stigler, G. (1974). Law enforcement, malfeasance, and the compensation of enforcers. Journal of Legal Studies, 3, 1-18. Retrieved from http://www.jstor.org/stable/724119

Becht, M., Bolton, P., \& Röell, A. (2005). Corporate governance and Control. European Corporate governance Institute. Retrieved from http://ssrn.com/abstract_id=343461

Betof, E., \& Seldman, M. (2006). How to use the organizational Savvy Model. Organizational Development and Leadership Sourcebook, 214-221.

Bernardin, H. J., \& Beatty, R. W. (1984). Performance Appraisal: Assessing Human behaviour at work. In Shipper, F., \& White, C. S. (Eds.), Mastery, Frequency and interaction of Managerial Behaviours Relative to sub unit Effectiveness. http://dx.doi.org/10.1023/A:1016920416152

Buchanan, D. A. (2007). You Stab My Back, I'll Stab Yours: Management Experience and Perceptions of Organization Political Behaviour. British Academy of Management, 1-16. http://dx.doi.org/10.1111/j.1467-8551.2007.00533.x

Bolman, L. G., \& Deal, T. E. (1997). Reframing Organizations (2nd ed.). San Francisco: Jossey-Bass.

Bolman, L. G., \& Deal, T. E. (1992). Leading and Managing: Effects of Context, Culture, and Gender. Educational Administration Quarterly, 28(3), 314-329. http://dx.doi.org/10.1177/0013161x92028003005 
Bolman, L. G., \& Deal, T. E. (1991). Leadership and Management Effectiveness: A multi-Frame, Multi-Sector Analysis. Human Resource Management, 30(4), 509-534. http://dx.doi.org/10.10.1002/hrm.3930300406

Bourdieu, P. (1990). The Logic of Practice. Cambridge, UK: Polity.

Bourgeois, L. J. III., \& Eisenhandt, K. M. (1987). Strategic Decision Processes in Silicon Valley: The Anatomy Of A “Living Dead". California Management Review, 30(1), 143-159.

Bourgeois, L. J. III., \& Eisenhardt, K. M. (1988). Strategic Decision Processes in High Velocity Environments: Four Cases In The Micro Computer Industry. Management Science, 34, 816-835. http://dx.doi.org/10.1287/mnsc-34.7.816

Campbell, A. (2003). The Role of the Parent company. In Faulkner, D. O. \& Campbell, A. (Eds.), The Oxford Handbook of Strategy: A Strategy Overview and Competitive Strategy. Oxford University Press.

Cammock, P., Nilakant, V., \& Dakin, S. (1995). Developing A lay Model of Managerial Effectiveness: A Social constructionist Perspective. Journal of Management Studies, 32(4), 443-447. http//dx.doi.org/10.1111/j.1467-6486.1995.tb00784.x

Chanlat, J. F. (1997). Conflict and Politics. In Sorge, A., \& Warner, M. (Eds.), Handbook of Organizational Behaviour (pp. 472-480). London: International Thomson.

Chandler, A. Jr. (1962). Strategy and Structure. Cambridge, Mass: MIT Press.

Costa, D. Y. (2006). The Art of Banking: Dominate the Banking Landscape and Win the War without Fighting a Battle. Livermore, C.A: Wingspan Press.

Collins, J. (2009). How The Mighty Fall (p. 62). New York: Harper Collins.

Collins, J., \& Porras, J. I. (2002). Built to Last: Successful Habits of Visionary Companies. New York: Harper Collins Publishers.

Cunliffe, A. L. (2011). Crafting qualitative research: Morgan and Smircich 30 years on. Organizational Research Methods, 14(4), 647-673. http://dx.doi.org/10.1177/1094428110373658

Christoe, E., Valachis, I., \& Anastasiadou, C. (2005). Research Methodology in Hospitability Industry: The Role of the Inquiry Paradigms. University of Aegean, Mihalon, Chos, Greece.

Cohen, J., Krishnamoorthy, G., Wright, A. (2009). Corporate Governance Mosaic and Financial Reporting Quality. In Ali-Shah, S. Z., Ali Butt, S., \& Hassan, A. (Eds.), Corporate Governance and Earnings Management: Empirical Evidence From Pakistani Listed Companies. Retrieved from http://ssm.com/abstract $=1732510$

Cleg, S. (1989). Radical revision: Power, discipline and Organization. Organizational Studies, 10(1), 97-115. http://dx.doi.org/10.1177/017084068901000106

Clegg, S. (2005). Vita Contemplativa: A life in Part. Organizational Studies, 26(2), 291-309. http://dx.doi.org/10.1177/0170840605049468

Davis, K. (1973). The case for and Against Business Assumption of Social Responsibilities. Academy of Management Journal, 16(2), 313. http://dx.doi.org/10.2307/255331

Dean, J. W., Brandes, P., \& Dhwardkar, R. (1998). Organizational Cynicism. Academy of Management Review, 23, 341-352. Retrieved from http://links.jstor.org/sici?sici=0363-7425\%28199804\%2923\%3A2\%3C341\%3A0C\%3E2.0.C0\%3B2-V

Ebhodaghe, I. U. (1994). Board/Management Practice and Distress in the Banking System. NDIC Quarterly.

Eisenhardt, K. M., \& Bourgeois, L. J. (1988). Politics of strategic Decision Making in High-Velocity Environments: Towards a Mid-range Theory. Academy of Management Journal, 31(4), 737-770. Retrieved from http://www.jstor.org/stable/256337

Elston, R., \& Johnson, W. (1994). Populations, Samples and Study design (2nd ed.). In Essentials of biostatistics. Philadelphia: Davis.

Ferris, G. R., Frink, D. D., Galarg, M. C., Zhou, J., Kacmar, K. M., \& Howard, J. L. (1996). Perceptions of Organizational Politics: Prediction, Stress Related Implications, and Outcomes. Human Relations, 49, 233-266. http://dx.doi.org/10.1177/001872679604900206

Ferris, G. R., \& Kacmar, K. M. (1992). Perceptions of Organizational politics. Journal of Management, 18(1), 93-116. http://dx.doi.org/10.1177/014920639201800107 
Fiedler, F. E. (1967). A Theory of leadership Effectiveness. New York: Mc Craw-Hill.

Foucault, M. (1977). Discipline and Punish: The Birth of the Prison. London: Allen Lane.

Gadamer, H. G. (1994). Truth and Method (Sheed and Ward LTD. Trans). New York: Continuum.

Gaventa, J. (1980). Power and Powerlessness: Quiesence and Rebellion in an Appalachian Valley. Oxford: Clarendon. In Hangaard, M. (Ed.), Reflections on seven ways of creating power. http://dx.doi.org/10.1177/1368431003006001562

Gaventa, J., \& Cornwall, A. (2001). Power and Knowledge. In P. Reason \& H. Bradbury (Eds.), Handbook of Action Research: Participative Inquiry and Practice. London: Sage Publications.

Gage, N. L. (1989). The Paradigm Wars and Their Aftermath. Educational Research, 18(7), 4-10. Retrieved from http://www.jstor.org/stable/1177163

Giddens, A. (1984). The Constitution of Society: Outline a theory of Structuration. Cambridge, UK: Polity.

Giddens, A. (1993). New rules of Sociological Methods: A positive critique of interpretive Sociologies. Cambridge, UK: Polity.

Gill, R. (2009). Theory and Practice of Leadership. London: Sage Publications Ltd.

Gillham, B. (2000). Case Study Research Methods. London and New York: Continum.

Graen, G. (1976). Role-Making processes within complex organizations. In Dunnette M. D. (Ed.), Handbook of Industrial and Organizational. Psychology, Rand Mc Naily: Chicago.

Griffin, R. W., \& Pustay, M. W. (1996). International Business: A managerial Perspective. Massachusetts: Addison-Wesley Publishing Company.

Griffin, C. (1985). Qualitative Methods and Cultural Analysis. In Burgess, R. (Ed.), Field Methods in the study of Education: Lewes Falmer.

Haber, S. H., Razo, A., \& Maurer, N. (2003). The Politics of Property Rights: Political Instability, Credible Commitments, and Economic Growth in Mexico. Cambridge, UK: Cambridge University Press.

Handy, C., \& Clegg, S. R. (1996). Some Dare Call It Power. In S. R. Clegg, C. Handy \& W. R. Nord (Eds.), Handbook of Organizational Studies. London: Sage.

Hardy, C. (1996). Understanding Power: Bringing About Strategic change. British Journal of Management, 7 , 3-16. http://dx.doi.org/10.1111/j.1467-8551.1996.tb00144.x

Hayward, M. L. A., \& Boeker, W. (1998). Power and Conflicts of Interest in Professional Firms: Evidence From Investment Banking. Administrative Science Quarterly, 43, 1-22. Retrieved from http://www.jstor.org/stable/2393589

Hermalin, B. E., \& Weisbach, M. S. (1998). Endegenously chosen boards of directors and their monitoring of the CEO. American Economic Review, 88(1), 96-118. Retrieved from http://links.jstor.org/sici?sici=0002-8282\%28199803\%2988\%3A1\%3C96\%3AECBODA\%3E2.0.CO\%3B2$\% 23$ origin=repec

Hendrickson, M. (2001). The long and bumping road to Glass-steagall Reform, A Historical and Evolutionary Analysis of Banking legislation. American Journal of Economics and Sociology. http://dx.doi.org/10.1111/1536-7150.00126

Holstein, J. A., \& Gubrium, J. F. (1994). Phenomenology, ethnomethodology and interpretive practice. In N. K Dezin \& Y. S. Lincoln (Eds.), Handbook of qualitative research. Thousand Oaks. CA: Sage.

Hodgkinson, C. A., \& Maree, J. G. (1998). Action Reseach: Some Guidelines for first-time Researchers in education. Journal of Education and Training, 19(2).

HitchCock, G., \& Hughes, D. (1995). Research and Teacher, a Qualitative Introduction to School-based Research. London: Routledge.

Huxham, C., \& Vangen, S. (2003). Researching Organizational Practice through Action research: Case Studies and design choices. Organizational Research Methods, $6(3), \quad 389$. http://dx.doi.org/10.1177/1094428103254454

Jacoby, S. (2005). Corporate governance and society. Challenge, 48(4), 69-87. http://dx.doi.org/10.1080/05775132.2005.11034302 
Jones, G. (1993). British Multinational Banking 1830-1990. New York: Oxford University Press Inc.

Jones G. (1995). Organization Theory Reading. Mass: Addison-westey.

Kashyap, A., Rajan, R., \& Stein, J. (2008). Rethinking Capital Regulation. In Erkens, D, Hung, M., \& Matos, P. (Eds.), Corporate Governance in the 2007-2008 Financial Crisis: Evidence from Financial Institutions worldwide. University of Sourthern California, Marshall School Business, Los Angeles.

Kacmar, K. M., \& Carlson, D. S. (1997). Further Validation of the Perceptions of Politics Scale (POPS): A Multiple Sample Investigation. Journal of Management, $23(5), \quad 630$. http://dx.doi.org/10.1177/014920639702300502

Keith, D., \& Blomstrom, R. L. (1971). Business Society and Environment: Social Power and Social Response (2nd ed.).

Kets De Vries, M. F. R., Vrignaud, P., \& Florent-Treacy, E. (2004). The Global Leadership Life Inventory: Development and Psychometric Properties of A 360-Degree Feedback Instrument. The International Journal of Human Resources Management, 15(3), 475-476. http://dx.doi.org/10.1080/0958519042000181214

Kelman, H. C., \& Hamilton, V. L. (2004). Crimes of Obedience: Toward A Social Psychology of Authority and Responsibility. In Beu, S. D., \& Buckley, R. R. (Eds.), This Is War: How The Politically Astute Achieve Crimes of Obedience Through The Use of Moral Disengagement. http://dx.doi.org/10.1016/j.leaqua.2004.05.007

Kemmis, S., \& McTaggart, R. (1988). The Action Research Planner (3rd ed.). Victoria, Australia: Deaken University Press.

Kotter, J. P. (1998). What leaders Really Do. Boston: Harvard Business School Press.

Kubr, M., \& Wallace, J. (1983). Successes and failures in meeting the Management Challenge: Strategies and their implementation. World Bank working Papers, No 585. Washington D.C., U.S.A.

Luthans, F., Rosencrantz, S., \& Hennessey, H. (1985). What do successful Managers Really Do? An Observation Study of Managerial Activities. The Journal of Applied Behavioural Sciences, 21(3), 255-270.

Liden, R. C., \& Graen, G. (1980). Generalizability of the vertical dyad Linkage Model of Leadership.

Levine, R. (2004). Finance \& growth: Theory, evidence, and mechanisms. In P. Aghion \& S. Durlauf (Eds.), Handbook of Economic Growth. Amsterdam: North-Holland Elsevier Publishers.

Lukes, S. (2005). Power: A Radical View (2nd ed.). Basing Stoke: Palgrave Macmillian.

Long, N., \& Long, A. (1992). Battlefields of Knowledge. The Interlocking of Theory and Practice in Social Research and Development. London, Routledge.

Malthus, T. R. (1798). An essay on the principles of population Chapter v. Oxford World's Classic reprint

Mamman, H., \& Oluyemi, S. A. (1998). Bank's Management issues and Restoring the Health of Nigerian Banks through improving the Quality of Management/employee. NDIC Quarterly, 4(4).

Martinko, M. J., \& Gardner, W. L. (1990). Structured Observation of Managerial Work: A Replication and $\begin{array}{lllll}\text { Synthesis. Journal of } & \text { Management }\end{array}$ http://dx.doi.org/10.1111/j.1467-6486.1990.tb00250x

Maitlis, S. (2004). Taking It From The Top: How CEOS Influence (And Fail To Influence) Their Boards. Organization Studies, 25, 1275-1311. http://dx.doi.org/10.1177/0170840604046318

Mitchell, R., Agle, B. R., \& Wood, D. J. (1997). Toward a Theory of Stakeholder Identification and salience: Defining The Principle Of who And What Really Counts. Academy of Management Review, 22(4), 853-886 Retrieved from http://www.jstor.org/stable/259247

Morse, J. M., Barrett, M., \& Mayan, M. (2002). Verification Strategies for establishing reliability and validity in qualitative research. International Journal of Qualitative Methods, 1(2).

Muldrow, T. W., Buckley, T., \& Schay, B. W. (2002). Creating High-performing organizations in the public sector. Human Resource Management, 341-352. http://dx.doi.org/10.1002/hrm.10045

Neuman, W. L. (2000). Social Research Methods (2nd ed.). London, Allyn and Bacon.

Ogbuile, N., \& Madueke, K. (2014). Union Bank Workers have 3 Months to leave. Business World, 8(21). 
Omoijiade, P. O. (2014a). The Global Financial Crisis and the Role of labour in the Nigerian Banking Sector. American Journal of Business and Management, 3(4), 199-205. http://dx.doi.org/10.11634/216796061403568

Omoijiade, P. O. (2014b). A Critical Assessment of Credit Management in the Nigeria banking sector. European Journal of Business and Management, 6(30), Retrieved from http://www.iiste.org/journals/index.php/EJBM/article/view/15621/15986

Omar, A. (2010). Unwholesome Actions of Mrs Funke Osibodu-led Union Bank Management Team. Letter to the Governor, Central Bank of Nigeria.

Osibodu, F. (2011). Withdrawal of Union recognition. Letter to the General Secretary, Association of Senior Staff of Banks, Insurance and Financial Institutions.

Parker, C. P., Dipboye, R. L., \& Jackson, S. L. (1995). Perceptions of Organizational Politics: An Investigation of Antecedents And Consequences. Journal of Management, 21(5), 891-912. http://dx.doi.org/10.1016/(95)90046-2

Parsons, T. (1960). Structure and Process in Modern Societies. Glencoe III. The Free Press.

Pettigrew, A. (1973). The politics of Organizational Decision Making. In Eisenhardt, K. M., \& Bourgeois, L. J. III. (Eds.), Politics of Strategic Decision Making in High-Velocity Environments: Toward a Midrange Theory. http://dx.doi.org/10.1017/S0003055400270093

Pfeffer, J. (1981). Power in organizations. In Ulkeryildiz, R. E. (Ed.), Political Tactics in Building Construction Industry from the Architect's perspective.

Pratch, L., \& Jacobowitz, J. (1997). The Psychology of leadership In Rapidly Changing Conditions: A Structural Psychological Approach. Journal of Genetic, Social and General Psychology, Monographs, 123(2).

Quinn, R. E. (1988). Beyond Rational Management. In Shipper, F., \& White, C. S. (Eds.), Behaviors Relative to sub unit Effectiveness. http://dx.doi.org/10.1177/001872679905200104

Robbins, S. P., \& Judge, T. A. (2009). Organizational Behaviour (13th ed.). USA: Pearson Education Inc.

Ronson, C. (2000). Real World Research: A Resource for Social Scientists and Practitioner-Researchers. M. A: Black well.

Riessman, C. K. (2002). Doing justice: Positioning the interpreter in narrative work. In W. Patterson (Ed.), Strategic Narrative: New Perspectives on the Power of Personal and Cultural Storytelling. Lanham MA and Oxford, UK, Lexington Books.

Sandberg, J. (2005). How do we justify knowledge produced within interpretive approaches? Organizational Research Methods, 8(1), 41-68. http://dx.doi.org/10.1177/1094428104272000

Saunders, M., Lewis, P., \& Thornhill, A. (2003). Research Method for Business Students. London: Prentice Hall.

Seldman, M., \& Betof, E. (2004). The organizational Savvy Model is a key resource in developing BD's high-performing, high integrity leaders: An Illuminated Path. Retrieved from https://www.bd.com/press/pdfs/TandD_An_Illuminated_Path.pdf

Shleifer, A., \& Vishny, R. W. (1998). The Grabbing Hand: Government Pathologies and their Cures. Cambridge, MA: Harvard University Press.

Smircich, L., \& Morgan, G. (1982). Leadership: The Management of Meaning. The Journal of Applied Behavioural Science, 18(3), 258-271. http://dx.doi.org/10.1177/002188638201800303

Stogdill, R. M. (1974). Handbook of leadership. In Kets de Vries, M. F. R., Vrignaud, P., \& Florent-Treacy, E. (Eds.), The New Global leaders: Percy Barnevik, Richard Branson, and David Simon and The Making of The International Corporation. San Francisco, CA: Jossey Bass.

Steiner, G. A., \& Steiner, J. F. (2006). Business, Government and Society: A Managerial Perspective, Text and Cases (11th ed.). Boston: Mc Craw-Hill.

Sonsino, S. (2002). Leadership Perspective. In Jenkins, M., \& Ambrosini, V. (Eds.), Strategic Management: A Multi-Perspective Approach. New York: Palgrave.

Treadway, D. C., Hochwarter, W. A., Ferris, G. R., Kacmar, C. J., Donglas, C,. Ammeter, A. P., \& Buckley, A. R. (2004). Leader Political Skill and Employee Reactions. The Leadership Quarterly, 15, 493-513.

OECD. (2008). Using the OECD Principles of Corporate Governance: A Boardroom perspective. Organization 
for Economic Co-Operation and Development, 139.

Valle, M., \& Witt, L. A. (2001). The Moderating Effect of Teamwork Perceptions on the Organizational Politics-Job satisfaction Relationships. The Journal of Social Psychology, 141(3), 379-388. http://dx.doi.org/10.1080/00224540109600559

Wayne, S. J., Liden, R. C., \& Sparrowe, R. T. (1994). Developing Leader-Member Exchanges: The Influence of Gender and Ingratiation. American Behavioral Scientist, 37, 697-714. http://dx.doi.org/10.1177/0002764294037005009

Williams, R. (2006). Seven Deadly habits of CEOS: Failure Rates as High as 70 percent in some companies. National Post.

Willcocks, S. G. (1992). Managerial Effectiveness and the Public Sector: A Health Service Example. International Journal of Public Administration, 5(5), 4-10. http://dx.doi.org/10. 1108/09513559210019352

Yukl, G. (1989). Leadership in organizations. In Yukl, G. (Ed.), Managerial leadership: A Review of Theory and Research. http://dx.doi.org/10.1177/014920638901500207

\section{Copyrights}

Copyright for this article is retained by the author(s), with first publication rights granted to the journal.

This is an open-access article distributed under the terms and conditions of the Creative Commons Attribution license (http://creativecommons.org/licenses/by/3.0/). 